Utah State University

DigitalCommons@USU

\title{
Breeding birds and small mammals in pole-sized lodgepole pine and small inclusions of aspen in central Colorado
}

\author{
V.E. Scott \\ G.L. Crouch \\ USDA For. Serv. Rocky Mt. For. Range Exp. Stn.
}

Follow this and additional works at: https://digitalcommons.usu.edu/aspen_bib

Part of the Forest Sciences Commons

\section{Recommended Citation}

Scott, V.E.; Crouch, G.L.; and USDA For. Serv. Rocky Mt. For. Range Exp. Stn., "Breeding birds and small mammals in pole-sized lodgepole pine and small inclusions of aspen in central Colorado" (1988). Aspen Bibliography. Paper 3284.

https://digitalcommons.usu.edu/aspen_bib/3284

This Contribution to Book is brought to you for free and open access by the Aspen Research at DigitalCommons@USU. It has been accepted for inclusion in Aspen Bibliography by an authorized administrator of DigitalCommons@USU. For more information, please contact digitalcommons@usu.edu.

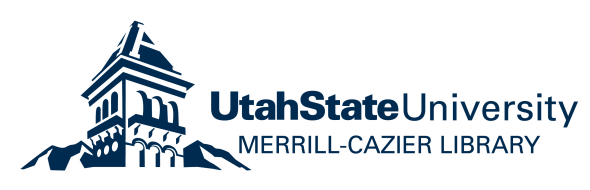




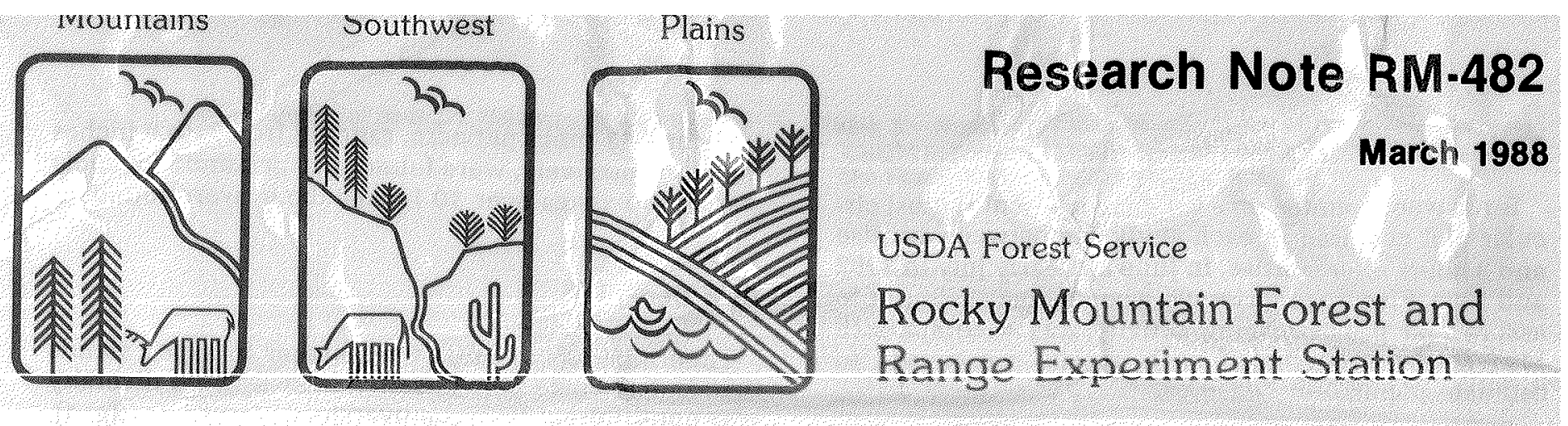

\title{
Breeding Birds and Small Mammals in Pole-Sized Lodgepole Pine and Small Inclusions of Aspen in Central Colorado
}

\author{
Virgil E. Scott' and Glenn L. Crouch ${ }^{2}$
}

\begin{abstract}
Numbers of birds and mammals in small aspen stands within a pole-sized lodgepole pine forest were compared with those found in the surrounding conifer forest. Some birds and one mammal that are usually associated with conifer forests were more abundant in the aspen than in the lodgepole pine. However, the aspen stands appear too small to provide habitat for aspen obligates.
\end{abstract}

Keywords: wildlife habitat, lodgepole pine, aspen

\section{Introduction}

Aspen (Populus tremuloides) is the major deciduous tree species in the central Rocky Mountains. In the western United States, aspen is a component of many forest types, but rarely covers extensive areas as the dominant overstory species except in Colorado and Utah (Daniel 1979). In the past, aspen in the West has had little market potential but demand has increased in recent years. The importance of the aspen community to forest birds has been documented by several authors (Flack 1976, Salt 1957, Winternitz 1976). Information about small aspen stands intermixed with coniferous forests and how they influence diversity and density of birds and small mammals is not available. This note compares species composition and densities of birds and small mammals in small, isolated aspen stands $\cong 0.1$ acre) within a lodgepole pine (Pinus contorta) forest with those found in the surrounding lodgepole pine.

\section{Study Area}

The study site is near the main entrance to the Fraser Experimental Forest in Colorado, at about 9,000 feet elevation (Alexander et al. 1985). The terrain is relative-

\footnotetext{
'Research Wildife Biologist, Retired, USDI Fish and Wildiffe Service, Fort Collins, Colo.

${ }^{2}$ Research Wildife Biologist, Rocky Mountain Forest and Range Experiment Station. Headquarters is in Fort Collins, in cooperation with Colorado State University.
}

ly gentle, and the overstory consists mostly of 65-yearold lodgepole pine, with scattered inclusions of small, isolated patches of aspen.

Understory vegetation in the lodgepole stands resembles that described by Hess and Alexander (1986) and others as occurring in Pinus contorta/Vaccinium scoparium plant associations. On the Fraser Experimental Forest, these lodgepole pine dominated communities are seral to Abies lasiocarpa/Vaccinium scoparium plant associations. Understories are dominated primarily by Vaccinium spp. but also include a few other low growing shrubs, a sparse cover of graminoids (mostly sedges), and a few forbs (Crouch 1986).

The small patches of aspen are also seral to the conifer associations. They contain a few conifers and somewhat more herbaceous cover than the lodgepole stands.

\section{Methods}

\section{Inventory Plots}

Fourteen near-circular stands of aspen, averaging about 0.1 acre, were selected for study. Fourteen similarsized sites were selected in lodgepole pine, at least 400 feet from the aspen stands. Within each study site, canopy cover was determined with a spherical densitometer, tree diameters at breast height were measured with a diameter tape, and heights were determined with a clinometer. 
Birds

Birds were counted on a 0.1 -acre (37-foot radius) circular plot centered in each study site between sunrise and 3 hours after sunrise, in June and early July in 1982 and 1983. Five inventories were conducted each year to assure that peak breeding activity was encompassed. ncans of the counts of each species were used to estimate population densities.

\section{Mammals}

Small mammals were trapped at five stations on each bird survey plot. One station was placed at the plot center and one 25 feet from the center in each cardinal direction. One rat trap and two museum specials were placed at each station and were baited with a peanut butteroatmeal mix. Traps were checked twice daily for 3 consecutive days. Data from each stand were considered one observation for analyses.

\section{Data Analyses}

Differences $(\mathrm{P}=0.10)$ in densities of birds and mammals between aspen and lodgepole sites were tested using two-way analyses of variance.

\section{Results and Discussion}

\section{Overstory Characteristics}

Tree diameters and heights tended to be greatest in the lodgepole and smallest in the aspen plots (table 1). The largest number of trees per acre $(2,442)$ occurred in the aspen and the fewest $(1,384)$ in the lodgepole plots. Aspen accounted for $82 \%$ and $1 \%$ of the trees in the aspen and lodgepole plots, respectively. Lodgepole pine accounted for virtually all of the trees in the conifer and $12 \%$ of those in the small aspen stands. A few subalpine fir (Abies lasiocarpa) and Engelmann spruce (Picea engelmannii) trees were present in both overstory categories.

Table 1.-Overstory characteristics of study plots in pole-sized lodgepole pine and small aspen stands on the Fraser Experimen. tal Forest, Colorado.

\begin{tabular}{ccc}
\hline & $\begin{array}{c}\text { Lodgepole pine } \\
\text { plots }\end{array}$ & $\begin{array}{c}\text { Small aspen } \\
\text { stands }\end{array}$ \\
\hline Canopy cover (\%) & 85 & 92 \\
Basal area (ft.2/acre) & 188 & 189 \\
Total trees (no./acre) & 1,384 & 2,442 \\
Composition (\%) & 1 & 82 \\
Aspen & 98 & 12 \\
Ledgepole pine & 0 & 1 \\
Engelmann spruce & 1 & 5 \\
Subalpine fir & 46 & 34 \\
Tree heights (ft.) & 4.5 & 3.3 \\
Diameters (in.) & 13 & 6 \\
Snags 6 in. d.b.h. (no./acre) & & \\
\hline
\end{tabular}

Six and 13 snags per acre, ranging from 6 to 9 inches d.b.h., respectively, were found in aspen and lodgepole stands. No snags over 10 inches d.b.h. were found.

\section{Bird Densities}

Total numbers of birds were higher in aspen stands than in lodgepole pine plots (table 2). Species diversity was not different between overstory categories (fig. 1).

Three of the four species of birds that were more abundant in aspen are generally considered birds of conifer forests. Of these, yellow-rumped warblers, ${ }^{3}$ usually found in conifers (Johnsgard 1979, Terres 1980), also prefer open woodlands or edges and inhabit aspen woodlands in the Rocky Mountains (Flack 1976). Most of the yellow-rumped warblers observed in aspen stands were using aspen trees. Red-breasted nuthatches and ruby-crowned kinglets also were more numerous in aspen; but more than one-half of the observed kinglets were in conifers in the aspen plots.

Dark-eyed juncos are ground feeding and ground nesting birds and generally prefer forests with grass-forb understories (Diem 1980). More juncos were counted in aspen than lodgepole plots.

Warbling vireos, birds of deciduous forests, were not observed in lodgepole plots and were counted in only three $(11 \%)$ of the aspen plots.

In the aspen plots, $81 \%$ of the mountain chickadees observed were in aspen trees, and the remainder were in the few conifers growing there.

No differences were detected among other species.

\section{Small Mammals}

The total number of small mammals caught was greater in aspen than in lodgepole pine plots (table 3).

Two species of shrews (Sorex cinereus, S. monticolus) were caught in aspen, but not in lodgepole plots (table 3). Few least chipmunks were caught, and there was no difference in numbers between overstory categories. Few deer mice were caught, and only on lodgepole plots. Southern red-backed voles are usually associated with conifer forests (Armstrong 1972) and prefer areas with slash or woody material on the ground (Gashwiler 1970). Regardless, red-backed voles-were more abundant in aspen than lodgepole plots in this study. The number of montane voles caught on aspen and lodgepole plots was not different.

\section{Conclusions}

Results indicate that the presence of small aspen stands within a nearly pure pole-sized lodgepole pine forest may result in an increase in the overall density of birds and mammals. However, data ${ }^{4}$ from a 20 -acre aspen stand

${ }^{3}$ Scientific names of birds and mammals are listed in tables 2 and 3.

${ }^{4}$ Data in the files of the senior author. 
Table 2, Estimated number of birds per 100 acres (standard error) in pole-sized lodgepole pine and small aspen stands on the Fraser Experimental Forest, Colorado.

\begin{tabular}{lcc}
\hline & Means of 1982 and 1983 \\
\cline { 2 - 3 } & Lodgepole pine & Aspen \\
\hline Gray jay & 19 & 12 \\
(Perisoreus canadensis) & $(10.6)$ & $(8.3)$ \\
Mountain chickadee & 50 & 82 \\
$\quad$ (Parus gambeli) & $(17.1)$ & $(13.8)$ \\
Red-breasted nuthatch & $2 \mathrm{~b}$ & $14 \mathrm{a}$ \\
$\quad$ (Sitta canadensis) & $(2.4)$ & $(6.2)$ \\
Ruby-crowned kinglet & $24 \mathrm{~b}$ & $62 \mathrm{a}$ \\
$\quad$ (Regulus calendula) & $(4.5)$ & $(19.1)$ \\
Townsend's solitaire & 0 & 4 \\
(Myadestes townsendi) & $(0.0)$ & $(2.4)$ \\
Hermit thrush & 12 & 12 \\
$\quad$ (Catharus guttatus) & $(5.9)$ & $(4.9)$ \\
Swainson's thrush & 0 & 5 \\
$\quad$ (Catharus ustulatus) & $(0.0)$ & $(4.7)$ \\
American robin & 7 & 10 \\
(Turdus migratorius) & $(5.2)$ & $(5.6)$ \\
Warbling vireo & 0 & 14 \\
$\quad$ (Vireo gilvus) & $(0.0)$ & $(9.8)$ \\
Yellow-rumped warbler & $12 \mathrm{~b}$ & $59 \mathrm{a}$ \\
(Dendroica coronata) & $(5.9)$ & $(14.5)$ \\
Dark-eyed junco & $26 \mathrm{~b}$ & $71 \mathrm{a}$ \\
$\quad$ (Junco hyemalis) & $(8.5)$ & $(20.0)$ \\
Pine grosbeak & 4 & 0 \\
(Pinicola enucleator) & $(2.4)$ & $(0.0)$ \\
$\quad$ Total birds & $156 \mathrm{~b}$ & $345 \mathrm{a}$ \\
& $(23.5)$ & $(49.2)$ \\
\hline & & \\
\hline
\end{tabular}

${ }^{1}$ Within species, means followed by no letter or the same letter are not different $(P=0.10)$.
Table 3.-Numbers (standard error) per plot of small mammals caught in pole-sized lodgepole pine and small aspen stands on the Fraser Experimental Forest, Colorado.!

\begin{tabular}{ccc}
\hline & \multicolumn{2}{c}{ Means of 1982 and 1983 } \\
\cline { 2 - 3 } & Lodgepole pine & Aspen \\
\hline Shrews & $0 \mathrm{~b}$ & $0.1 \mathrm{a}$ \\
(Sorcx sp.) & $(0.00)$ & $(0.04)^{\prime}$ \\
Least chipmunk & 0.3 & 0.3 \\
(Tamias minimus) & $(0.07)$ & $(0.08)$ \\
Deer mouse & 0.4 & 0 \\
(Peromyscus maniculatus) & $(0.08)$ & $(0.00)$ \\
Southern red-back vole & $1.6 \mathrm{~b}$ & $2.9 \mathrm{a}$ \\
(Clethrionomys gapperi) & $(0.26)$ & $(0.29)$ \\
Montane vole & 0.1 & 0.4 \\
(Microtus montanus) & $(0.03)$ & $(0.23)$ \\
Total mammals & $2.4 \mathrm{~b}$ & $3.7 \mathrm{a}$ \\
& $(0.27)$ & $(0.41)$ \\
\hline
\end{tabular}

${ }^{1}$ Within species, means followed by no letter or the same letter are not significantly different $(P=0.10)$.

near the study area, and from two other aspen study sites in western Colorado, suggest that the small aspen patches described here were too small to attract aspen obligate birds and mammals. These stands, although aspen dominated, do not have the area or the understories that are typical of well-developed, larger-sized stands.

However, based on numbers of species and numbers of birds and mammals, the small aspen stands studied here are much more productive than the lodgepole pine forest that surrounds them.

\section{Literature Cited}

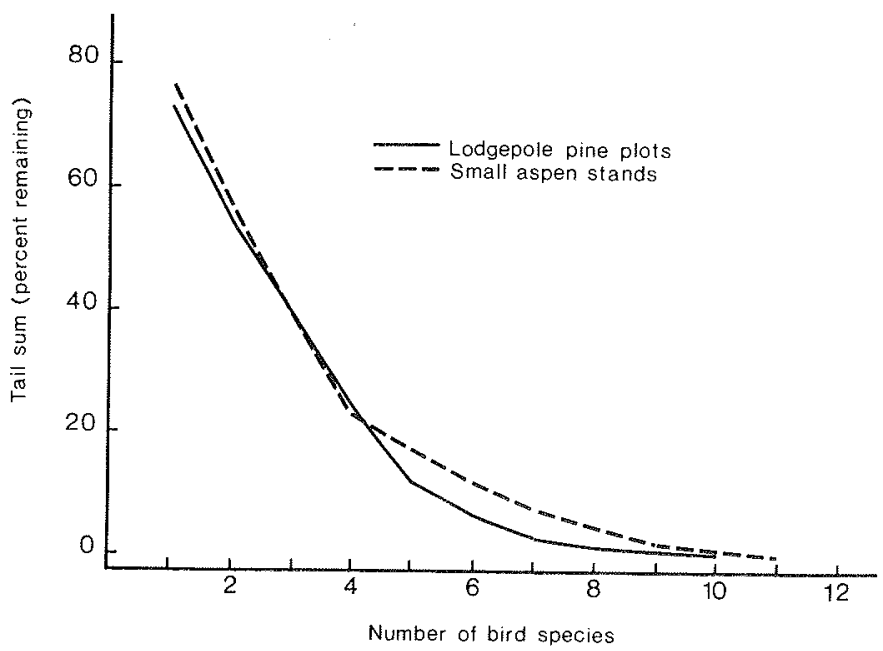

Figure 1.-Species diversity profile of bird communities in pole. sized lodgepole pine and small aspen stands on the Fraser Ex. perimental Forest, Colorado. Lines in the profile that do not cross indicate differences in species diversity (Patil and Taille 1979).
Alexander, Robert R.; Troendle, Charles A.; Kaufmann, Merrill R.; Shepperd, Wayne D.; Crouch, Glenn L.; Watkins, Ross K. 1985. The Fraser Experimental Forest, Colorado: research program and published research 1937-1985. Gen. Tech. Rep. RM-118. Fort Collins, CO: U.S. Department of Agriculture, Forest Service, Rocky Mountain Forest and Range Experiment Station. $46 \mathrm{p}$.

Armstrong, David M. 1972. Distribution of mammals in Colorado. Museum of Natural History, University of Kansas, Monograph No. 3, 445 p.

Crouch, Glenn L. 1986. Effects of thinning pole-sized lodgepole pine on understory vegetation and large herbivore activity in central Colorado. Res. Pap. RM-268. U.S. Department of Agriculture, Forest Service, Rocky Mountain Forest and Range Experiment Station. $10 \mathrm{p}$.

Daniel, T. W. 1979. The middle and southern Rocky Mountain region. In: Regional silviculture of the United States. John W. Barrett, ed. New York, NY: John Wiley and Sons. 277-340. 
Diem, Kenneth L. 1980. Ponderosa pine bird communities. In: Management of western forests and grasslands for nongame birds: proceedings of the workshop; 1980 February 11-14, Salt Lake City, UT. Gen. Tech. Rep. INT -86. Ogden, UT. U.S. Department of Agriculture, Forest Service, Intermountain and Rocky Mountain Forest and Range Experiment Stations: $170-194$.

Flack, J. A. Douglas. 1976. Bird populations of aspen forests in western North America. American Ornithologists Union, Ornithological Monographs No. $19,97 \mathrm{p}$.

Gashwiler, Jay S. 1970. Plant and animal changes on a clearcut in west-central Oregon. Ecology 51: $1018-1026$.

Hess, Karl, Alexander, Robert R. 1986. Forest vegetation of the Arapaho and Roosevelt National Forests in north-central Colorado: a habitat type classification. Res. Pap. RM-266. Fort Collins, CO: U.S. Department of Agriculture, Forest Service, Rocky Mountain Forest and Range Experiment Station, 48 p.

Johnsgard, Paul A. 1979. Birds of the Great Plains. Lincoln, NE: University of Nebraska Press. $539 \mathrm{p}$

Patil, G. P, Taillie, C. 1979. A study of diversity profiles and orderings for a bird community in the vicinity of Colstrip, Montana. In: Contemporary quantitative ecology and related econometrics. Patil, $\mathrm{K}, \mathrm{P}$; Rosenzweig, M, eds. Fairland, MD: International Cooperative Publication House, 23-48.

Salt, C. W. 1957. An analysis of avifauna in the Teton Mountains and Jackson Hole, Wyoming, Condor 59: 373-393.

Terres, John K. 1980. The Audubon Society Encyclopedia of North American Birds. New York, NY: Alfred Knopf, Inc. 1109 p.

Winternitz, Barbara A. 1976. Temporal change and habitat preferences of some montane breeding birds. Condor 78: $383-393$. 